\title{
Att tala för andra Översättning ur ett transperspektiv
}

Robinson, Douglas. 2019. Transgender, Translation, Translingual Address. New York: Bloomsbury Academic University Press. (248 sidor)

I BOKEN tRANSGENDER, Translation, Translingual Address tar den Hong Kongbaserade Douglas Robinson upp frågor som rör vad han kallar transspråkiga [translingual] dialoger om översättning och tilltal mellan cis- och transpersoner. Boken diskuterar olika typer av gränsöverskridanden inom ramen för översättning, kön och tilltal.

Utgångpunkten är den anglosaxiska överensstämmelsen mellan orden transgender, translation och translingual. Förledet trans- är latin och betyder över. I engelska används det såväl i begreppet translation [översättning], transgender (som i Robinsons terminologi snarast kan översättas till transidentitet) och translingual [transspråkig]. På svenska är den betydelsemässiga överensstämmelsen inte språkligt lika tydlig då translation ju blir översättning på svenska. Men naturligtvis finns den. Alla begreppen handlar ju om någon typ av överföring eller passage mellan olika områden. I fallet med översättning handlar det om att överföra ett innehåll från ett språk till ett annat, i fallet med transidentitet handlar det om en subjektsposition som på något sätt överflyglar gränsen mellan de binära polerna kvinnligt och manligt. Transspråkighet handlar om passager över olika språkgränser, passager de flesta av oss obesvärat gör dagarna igenom. Vi transspråkar exempelvis när vi deltar i ett 
seminarium och diskuterar en engelsk text på svenska, samtidigt som vi under bordet messar om vad som pågår med vår syster på vårt förstaspråk danska. Boken handlar alltså inte om transfrågor som sådana, utan mer specifikt om dialoger och samtal om översättning och olika typer av handlingar som innebär att en pratar för en annan, mellan gemenskaper, inte nödvändigtvis endast gemenskaper sammanhållna av transpersoner.

Vad innebär det exempelvis att det i språkliga termer är så kallad homospråkighet [homolingual] som är det normativa, alltså att tala samma språk som den en är inbegripen i dialog med? Medan det i sexuella termer ju är det heterosexuella som är det normativa - det vill säga att en ska inleda relationer med personer av olikt kön? Och hur kan en översättare, som ju står emellan två språk i en värld som ser individer som i grunden enspråkiga (att vi har ett modersmål, inte flera) göra anspråk på att ha en entydig subjektsposition?

Det är komplicerat och komplext, och Robinson säger själv att boken i sig självär trans, snarare än cis. Den är "an experimental participation in communal acrossness" (ur förordet).

Författaren tar också upp den brännande frågan kring vem som har rätt att tala för vem. Vilken rätt har han, som cisman, att tala både för cis- och transpersoner? Obekväm med samhällets maskulinitetsnormer men inte tillräckligt obekväm för att ta detta som ett ifrågasättande av sin maskulina identitet, lyckades han anpassa sig tillräckligt för att "passera" som man och dessutom åtnjuta alla de privilegier som medföljer denna position. Trots detta känner han sig aldrig helt som en man utan som om han, trots att han inte uttrycker någon transidentitet, befinner sig någonstans mellan genuspolerna.

Bokens kapitel har olika fokus. Det första kapitlet handlar om varför även cisnormativa översättare måste intressera sig för frågor om översättning och trans. Den utgår från en maorisk beteckning, takatāpui, som antingen kan antas referera till homosexuella män [gay men] eller nära manliga vänner [close male friends]. Då beteckningen är dubbeltydig måste översättare, oavsett cis- eller transidentitet, både känna till och kunna överföra betydelsen från käll- till målspråket. 
Det andra och tredje kapitlet utgår från Jurij Lotmans teori om semiotiska fält och diskuterar vad denna har för konsekvenser för översättning mellan finska och engelska, med utgångspunkten i en finsk novell av Otto Lehtinen.

Det fjärde kapitlet tar sig an Gilles Deleuzes rhizomatik och diskuterar hur en, i analogi med "becoming-woman", kan tala om "becomingtrans". Finns det överensstämmelser här också vad gäller skillnader mellan så kallad "'molar' feminism" á la Rosi Braidotti med flera och "'molecular' feminism" med utgångspunkt i Louise Burchills tankar? Och vad är kopplingarna mellan så kallade boi- och grrrl-identiteter?

I det avslutande kapitlet försöker Robinson dra ihop några av de spretiga resonemang som förts i bokens fyra kapitel genom att diskutera olika teoretiska förståelser av queerblivanden, framför allt utifrån Judith Butlers och Kate Bornsteins arbeten.

Under skrivandet av denna recension hade jag stora problem med att översätta de engelska termerna till svenska utan att förlora poängen i resonemangen, vilket endast poängterar relevansen för många av de frågor som Robinson tar upp i sin bok. Då boken också handlar om översättning blev metalagren ofta för många för att jag skulle klara av att både ta till mig resonemangen och förmå värdera dem i akademiska termer. Men för översättningsteoretiker med intresse av transfrågor är boken säkerligen ett intressant nytillskott, då den på ett teoretiskt välgrundat sätt försöker ta sig an frågor som rör översättning i relation till genusoch transfältets heterogena språkliga empiri. Att något är svårt är ju ingen anledning att låta bli att försöka ta sig an det. Men mer teoretiskt bevandrade akademiker än jag får avgöra ifall Robinsons resonemang kan utgöra grunden för en vidare diskussion. För mig som feministisk språkvetare var boken en spännande utmaning och en påminnelse om vilken oändlig källa till nya forskningsfrågor som finns i skärningspunkten mellan språkvetenskap och genusteori. 